\title{
The times they are a-changin'
}

\author{
Lawrence H. Cohn, MD
}

Reflecting on the recent American Association for Thoracic Surgery (AATS) meeting in Toronto on May 1-5, 2010, I was impressed by the many innovative papers, symposia, and exhibits on the diagnosis and treatment of the entire spectrum of cardiovascular and thoracic disease, including the critical care symposium, supporting the service-line platform of the Journal, which was discussed in my editorial in 2008. ${ }^{1}$ The continued evolution of the service-line concept in the field of cardiovascular and thoracic surgery has been rapid and truly impressive as less invasive therapies such as percutaneous valves, endobronchial interventions, robotic surgery, and vascular stenting continue to expand. ${ }^{2}$

One could find no better examples of the service-line concept than the hybrid thoracic and cardiac operating rooms displayed at the AATS, assembled by Dr Raphael Bueno and Dr John Byrne. Attendance at both of these venues was very high, including more than 100 hospital executives who were invited to tour the operating rooms as the demand for hybrid operating rooms is escalating nationally and internationally.

The interest in the service-line concept is evidence that times are indeed changing and the need for close interaction with our medical colleagues is becoming imperative. Dr Alec Patterson, ${ }^{3}$ in his AATS presidential address, emphasized the importance of multidisciplinary teamwork and service integration going forward for optimal training and patient care. The question is, how will we, as a specialty, rise to the occasion to ensure that our trainees will have adequate exposure to the newer advancements in our field? Many of our international training programs are already exposing their trainees and young colleagues to these service-line innovations; therefore, I believe the American Board of Thoracic Surgery (ABTS) and the Residency Review Committee should consider a mandatory rotation for cardiothoracic surgeons in interventional radiology, cardiology, pulmonology, gastroenterology, and vascular surgery. This will not lead to certification in these areas, but it will give cardiothoracic trainees exposure to skills necessary for new therapies. This training should be approached as a "team effort," not "turf warfare." Making these rotations mandatory for ABTS qualification would make it necessary for the Accreditation Council for Graduate Medical Educa-

\footnotetext{
From the Division of Cardiac Surgery, Brigham and Women's Hospital, Boston, Mass.

Address for reprints: Lawrence H. Cohn, MD, the Division of Cardiac Surgery, Brigham and Women's Hospital, 75 Francis St, Boston, MA 02115 (E-mail: lcohn@partners.org).

J Thorac Cardiovasc Surg 2010;140:3-4

$0022-5223 / \$ 36.00$

Copyright (C) 2010 by The American Association for Thoracic Surgery

doi:10.1016/j.jtcvs.2010.05.008
}

tion counterpart programs to accommodate our trainees. The service-line concept is gaining momentum and should be at the top of our agenda to implement as it supports our initiative as cardiovascular and thoracic surgeons to provide the best possible care for our patients.

Comparative effectiveness research (CER) is becoming a household term in Washington, DC. This concept theoretically has merit to scientifically define the best strategy of disease treatment. CER has now fully blossomed in Washington, and millions of research dollars have been set aside to support the evaluation of medical and surgical treatment in areas including device technology, drug therapies, and administrative systems. Participation in these studies will be crucial as President Obama's health care plan evolves and the public becomes aware of the uncertainties of some new therapies. Such projects as the optimal treatment for ischemic mitral regurgitation or the best treatment for small cell lung cancer are some of the topics now being inaugurated for national studies. The CER article ${ }^{4}$ in the reference list outlines the rationale for supporting this important endeavor. In addition, the expert commentary by Timothy Gardner and Patrick O'Gara ${ }^{5}$ in this Journal summarizes the combined medical/surgical approach to CER.

In closing I would like to thank the entire Editorial staff and the ad hoc reviewers of the Journal for their outstanding work this past year. As our specialty expands by leaps and bounds, we need intense and timely reviews of the excellent manuscripts submitted to the Journal and we could not accomplish this without our editorial reviewers. I would like to welcome Drs Niv Ad, Joseph Dearani, Victor Ferraris, Sheng-Shou Hu, Paul Kurlansky, and Y. Joseph Woo to the Editorial Board. I would like to give special thanks to our retiring Editorial Board members, Drs Carl Lewis Backer, Bartley P. Griffith, David H. Harpole, and Francis G. Spinale, as well as Dr Marko Turina, new editor of CTSNet, and Dr Michael Maddaus, newly appointed co-editor of Seminars in Thoracic and Cardiovascular Surgery. Their exemplary performance has been greatly appreciated.

The future of our specialty is evolving. As Bob Dylan said:

Please heed the call

Don't stand in the doorway

Don't block up the hall

For he that gets hurt

Will be he who has stalled...

For the times they are are a-changin'*

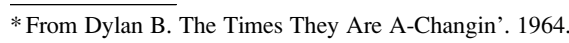




\section{References}

1. Cohn LH. Update on the cardiovascular and thoracic service-line concept. J Thorac Cardiovasc Surg. 2008;136:1403.

2. Cohn LH. Future directions in cardiac surgery. Am Heart Hosp J. 2006;4:174-8.

3. Patterson GA. Non solus-a leadership challenge. J Thorac Cardiovasc Surg. In press.
4. Iglehart JK. Prioritizing comparative-effectiveness research-IOM recommendations. N Engl J Med. 2009;361:4.

5. Gardner TJ, O'Gara PT. The Cardiothoracic Surgery Network: randomized clinical trials in the operating room. J Thorac Cardiovasc Surg. 2010;139: 830-4. 